Jurnal Ners Volume 4 Nomor 1 Tahun 2020 Halaman 81 - 88

JURNAL NERS

Research \& Learning in Nursing Science

PNIVERSITAS

http://journal.universitaspahlawan.ac.id/index.php/ners

\title{
PERSEPSI MAHASISWA UNIVERSITAS PAHLAWAN TUANKU TAMBUSAI TERHADAP PERKULIAHAN DARING SEBAGAI SARANA PEMBELAJARAN SELAMA MASA KARANTINA COVID-19
}

\author{
Muhammad Nurman \\ Program Studi Profesi Ners \\ Universitas Pahlawan Tuanku Tambusai \\ m.nurman311277@gmail.com
}

\begin{abstract}
Abstrak
Perkuliahan online atau yang biasa disebut daring merupakan salah satu bentuk pemanfaatan internet yang dapat meningkatkan peran mahasiswa dalam proses pembelajaran. Analisis deskriptif pada penelitian ini mengkaji persepsi mahasiswa Universitas Pahlawan Tuanku Tambusai mengenai model pembelajaran daring terkait pemanfaatan media, gaya belajar, dan jenis komunikasi tertentu yang digemari mahasiswa untuk membantu mereka menghasilkan output yang lebih baik dari kegiatan belajar mengajar secara daring. Jumlah sampel dalam penelitian ini adalah 806 mahasiswa Universitas Pahlawan Tuanku Tambusai yang telah terlibat dalam pembelajaran daring selama masa karantina Covid-19. Hasilnya didapatkan bahwa media pembelajaran daring yang paling digemari ialah Google Classroom. Sebesar 89,1\% dari mahasiswa Universitas Pahlawan Tuanku Tambusai sudah mengenal berbagai media pembelajaran daring tersebut sebelum perkuliahan daring dimulai. Selain itu, pola komunikasi yang paling diminati oleh mahasiswa ialah pola semi dua arah. Diperlukan adanya penelitian lebih lanjut terhadap penelitian pembelajaran daring dengan berbasis masalah, kolaboratif, dan model lainnya.
\end{abstract}

Kata kunci : Persepsi, Perkuliahan Daring, Covid-19

\begin{abstract}
Abtract
Online lectures is one form of internet utilization that can enhance the role of students in the learning process. Descriptive analysis in this study examines students' perceptions of the University Pahlawan Tuanku Tambusai on online learning models related to the use of media, learning styles, and certain types of communication that are popular with students to help them get better output from online learning activities. The number of samples in this study were 806 students of the University Pahlawan Tuanku Tambusai who had been involved in online learning during the Covid-19 quarantine period. The results found that the most popular online learning media are Google Classroom. As many as 89,1\% of University Pahlawan Tuanku Tambusai students are familiar with various online learning media before online lectures begin. In addition, the communication pattern that is most popular by students is the semi-two-way pattern. Further research is needed on online learning research with problem- based, collaborative, and other models.
\end{abstract}

Keywoards: Perception, Online lectures, Covid-19

@ Jurnal Ners Prodi Sarjana Keperawatan \& Profesi Ners FIK UP 2020

$\triangle$ Corresponding author :

Address : Jl. Tuanku Tambusai No. 23 Bangkinang

Email : m.nurman311277@gmail.com

Phone : 081378481097 


\section{PENDAHULUAN}

Saat ini, metode pembelajaran di berbagai institusi pendidikan tidak selalu harus diselenggarakan melalui tatap muka. Terdapat model pembelajaran lain yang bisa digunakan oleh tenaga pengajar sebagai media penyampaian ilmu pengetahuan, yaitu pembelajaran daring dan pembelajaran campuran (kombinasi dari dua metode pembelajaran yaitu tatap muka dan pembelajaran daring). Pembelajaran full online dianggap kurang dapat mengakomodasi seluruh kebutuhan pembelajaran (Tuncay dkk, 2011), maka pembelajaran campuran atau blended learning menjadi salah satu alternative yang cukup diminati oleh tenaga pengajar.

Pada dasarnya, metode pembelajaran daring tidak menuntut mahasiswa untuk hadir dikelas. Mahasiswa dapat mengakses pembelajaran melalui media internet. Menurut Lashley (2014) penggunaan teknologi yang tersedia disekitar kita apabila diimbangi dengan diskusi dan panduan maka akan menjadi alat pengembangan keterampilan berpikir tingkat tinggi. Perkembangan teknologi ini memudahkan penggunaan internet untuk mengakses materi pembelajaran, berinteraksi dengan konten, instruktur, dan pelajar lain; dan untuk mendapatkan dukungan selama proses belajar, untuk memperoleh pengetahuan, untuk membangun pribadi makna, dan tumbuh dari pengalaman belajar. Umumnya, setiap tenaga pengajar / dosen dalam institusi perguruan tinggi dapat memiliki pertimbangan sendiri untuk memilih model pembelajaran mana yang dianggap paling cocok untuk diselenggarakan pada pembelajaran mahasiswa.

Berkaitan dengan adanya wabah Covid-19 pada awal tahun 2020, pemerintah kemudian mengeluarkan himbauan untuk melakukan kegiatan pembelajaran dari rumah (Fajrian, 2020). Hal ini dilakukan demi memutus rantai penyebaran virus dan menjaga keamanan serta keselamatan peserta didik dan tenaga pendidik. Dengan adanya himbauan tersebut maka proses pembelajaran pun dilakukan dari rumah dengan memanfaatkan teknologi dan media internet. Beberapa institusi perguruan tinggi yang sebelumnya melakukan pembelajaran tatap muka di kampus masing-masing, kini harus mengadaptasi model pembelajaran e-learning atau yang biasa disebut pembelajaran daring.
Pembelajaran daring memberikan manfaat bagi kedua belah pihak, baik dosen maupun mahasiswa (Singh, 'donoghue, \& Worton, 2005). Bagi mahasiswa, pembelajaran daring muncul sebagai salah satu metode alternatif belajar yang tidak mengharuskan mereka untuk hadir di kelas. Pembelajaran daring juga akan membantu mahasiswa membentuk kemandirian belajar dan juga mendorong interaksi antar mahasiswa. Sedangkan bagi dosen metode pembelajaran daring hadir untuk mengubah gaya mengajar konvensional yang secara tidak langsung akan berdampak pada profesionalitas kerja. Model pembelajaran daring juga memberi peluang lebih bagi dosen untuk menilai dan mengevaluasi progress pembelajaran setiap mahasiswanya secara lebih efisien.

Dengan adanya himbauan tersebut, maka proses pembelajaran di Fakultas Ekonomi Universitas Teuku Umar dapat disebut sebagai blended learning. Blended learning merupakan campuran dari pembelajaran online dan ruang kelas yang berisi beberapa fasilitas kursus online dengan kehadiran komunikasi tatap muka. Terdapat dua elemen penting dalam mendefinisikan blended learning yaitu instruksi online dan tatap muka (Rovai \& Jordan, 2004 ; Picciano, 2006). Blended learning menjadikan situasi belajar lebih aktif dan fleksibel. Dosen dan mahasiswa harus memanfaatkan sumber daya yang tersedia untuk kesuksesan model belajar ini. Dosen juga diminta untuk menyediakan lebih banyak waktu bagi mahasiswanya baik dalam kelompok kecil ataupun secara individual (Oh \& Park, 2009). Selain itu, blended learning berpotensi untuk berubah pengalaman dan hasil mahasiswa melalui pembelajaran (Davis \& Fill, 2007). Metode pembelajaran daring akan menjadi lebih efisien ketika dicampur dengan pembelajaran tradisional (Hameed, Badii, \& Cullen, 2008), tujuan penelitian ini adalah untuk mengkaji persepsi mahasiswa terhadap model pembelajaran daring yang diterapkan di Universitas Pahlawan Tuanku Tambusai selama masa karantina Covid-19.

\section{METODE PENELITIAN \\ Desain Penelitian}

Desain penelitian ini adalah berupa Analisis deskriptif yang akan mengkaji persepsi mahasiswa Universitas Pahlawan Tuanku Tambusai 
mengenai model pembelajaran daring. Melalui beberapa pendekatan seperti media yang digunakan, jenis komunikasi, dan gaya belajar mahasiwa.

\section{Lokasi dan Waktu Penelitian}

Penelitian di laksanakan di Universitas Pahlawan Tuanku Tambusai. Waktu pelaksanaan penelitian dilaksanakan di semester Genap tahun ajaran 2019/2020, pada tanggal 15 Mei sampai dengan 10 Juli 2020.

\section{Populasi}

Populasi adalah keseluruhan subyek atau objek penelitian yang akan diteliti (Notoatmodjo, 2012). Adapun populasi dalam penelitian ini yaitu mahasiswa Universitas Pahlawan Tuanku Tambusai, yaitu yang berjumlah 806 mahasiswa.

\section{Sampel}

Sampel adalah sebagian yang diambil dari keseluruhan objek yang akan diteliti dan dianggap mewakili seluruh populasi (Notoadmodjoj, 2012). Teknik pengambilan sampel dalam penelitian ini adalah teknik total sampling, yaitu teknik penetapan sampel dengan cara mengambil seluruh anggota populasi sebagai responden atau sampel (Sugiyono, 2013). Sampel yang diambil peneliti untuk penelitian sebanyak 806 mahasiswa.

\footnotetext{
Alat Pengumpulan Data

Data persepsi diperoleh dari kuesioner yang dibagikan kepada para mahasiswa melalui google form selama satu bulan menjalankan proses belajar mengajar dengan metode daring. Penelitian ini menggunakan populasi mahasiswa Universitas Pahlawan Tuanku Tambusai. Pengumpulan sample dilakukan dengan metode non probabilitas sampling dengan pendekatan convenience sampling. Jumlah anggota populasi yang bersedia menjadi responden dalam penelitian ini adalah 806 mahasiswa Universitas Pahlawan Tuanku Tambusai yang telah terlibat dalam pembelajaran daring selama masa karantina Covid-19. 806 orang responden terbagi secara merata dari setiap program studi yang ada di Universitas Pahlawan Tuanku Tambusai. Mahasiswa tersebut diminta kesediannya untuk mengisi kuesioner yang sudah dibagikan secara daring ketika kegiatan pembelajaran.
}

\section{Analisa Data}

Analisa data yang digunakan adalah analisa univariat. Analisa univariat yang dilakukan terhadap tiap variabel dari hasil penelitian. Pada umumnya dalam analisis ini hanya menggambarkan distribusi dan persentase dari tiap variabel, sehingga diketahui variasi dari variabel pada penelitian ini tentang persepsi mahasiswa terhadap model pembelajaran daring yang diterapkan di Universitas Pahlawan Tuanku Tambusai selama masa karantina Covid-19.

\section{HASIL DAN PEMBAHASAN \\ Analisis Univariat}

Berdasarkan data kuesioner yang sudah diisi oleh mahasiswa sebanyak 806 orang dengan hasil sebagai berikut :

\section{Diagram 4.1}

Distribusi Frekuensi Persepsi Mahasiswa Universitas Pahlawan Tuanku Tambusai terhadap Perkuliahan Daring berdasarkan Fakultas
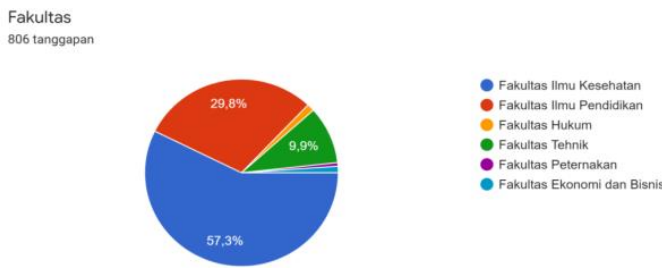

Berdasarkan data diatas didapatkan hasil bahwa dari 6 Fakultas yang ada di Universitas Pahlawan Taunku Tambusai sebagian besar yang memberikan persepsi terhadap perkuliah daring adalah Fakultas Ilmu Kesehatan, yaitu 57,3 \%.

\section{Diagram 4.2}

Distribusi Frekuensi Persepsi Mahasiswa Universitas Pahlawan Tuanku Tambusai terhadap Perkuliahan Daring berdasarkan Program Studi
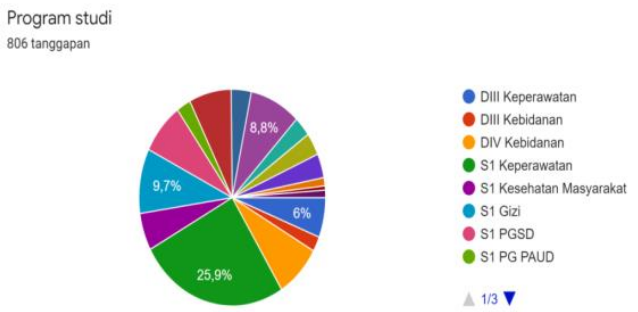
Program studi

806 tanggapan
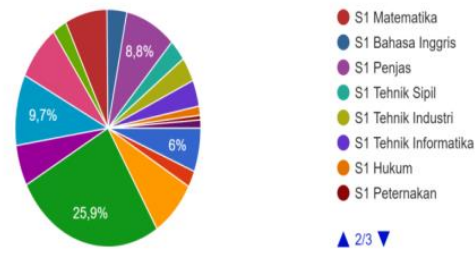

Berdasarkan tabel 4.2 diatas dapat dilihat bahwa dari 18 Program Studi yang ada di Universitas Pahlawan Taunku Tambusai yang paling banyak memberikan persepsi terhadap perkuliah daring adalah Progra Studi S1 Keperawatan, yaitu 25,9 $\%$.

\section{Diagram 4.3}

Distribusi Frekuensi Persepsi Mahasiswa Universitas Pahlawan Tuanku Tambusai terhadap Perkuliahan Daring berdasarkan Semester

Semester
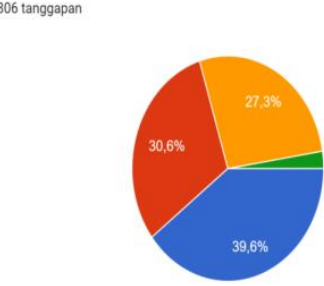

$$
\begin{aligned}
& -2 \\
& -4 \\
& -6 \\
& -8
\end{aligned}
$$

Dari diagram di atas dapat dijelaskan bahwa Mahasiswa Universitas Pahlawan Tuanku Tambusai memberikan tanggapan terkait perkuliahan daring berdasarkan semester, yang paling banyak memberikan tanggapan adalah program studi pada semester 2 yaitu 39,6\%.

\section{Diagram 4.4}

Distribusi Frekuensi Persepsi Mahasiswa Universitas Pahlawan Tuanku Tambusai terkait Kesan Perkuliahan Daring

Bagaimana Kesan anda terkait perkuliahan Daring/Online 801 tanggapan

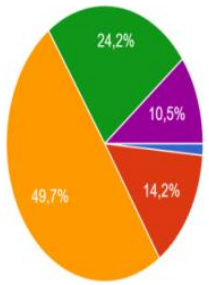

Sesuai dengan diagram di atas menggambarkan bahwa Persepsi Mahasiswa Universitas Pahlawan Tuanku Tambusai memberikan kesan terkait perkuliahan daring, sebagian besar menyatakan hanya kadang-kadang menyenangkan, yaitu sebanyak 49,7\% Responden.

\section{Diagram 4.5}

Distribusi Frekuensi Persepsi Mahasiswa

Universitas Pahlawan Tuanku Tambusai terkait aplikasi yang digunakan saat Perkuliahan Daring

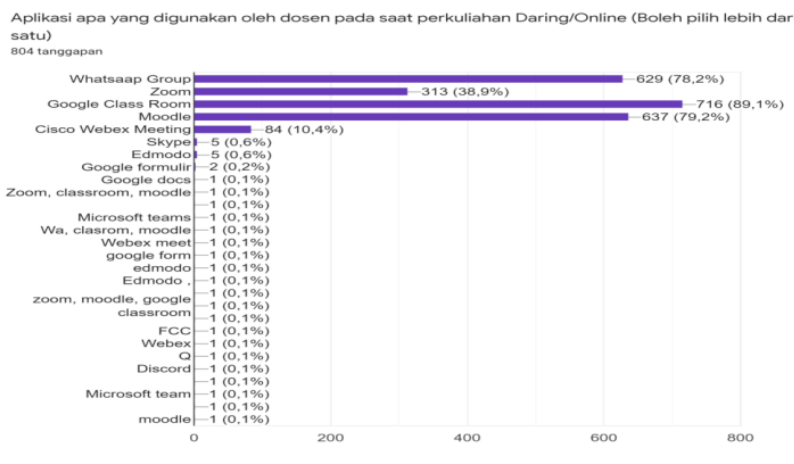

Berdasarkan diagram dari 4.5 di atas dapat digambarkan bahwa Persepsi Mahasiswa Universitas Pahlawan Tuanku Tambusai terhadap perkuliahan daring berdasarkan aplikasi yang digunakan oleh dosen pada saat perkuliahan daring sebagian besar menggunakan aplikasi google class room yaitu dengan persentase $89,1 \%$.

\section{Diagram 4.6 \\ Distribusi Frekuensi Persepsi Mahasiswa Universitas Pahlawan Tuanku Tambusai terhadap Perkuliahan Daring berdasarkan aplikasi yang disukai mahasiswa}

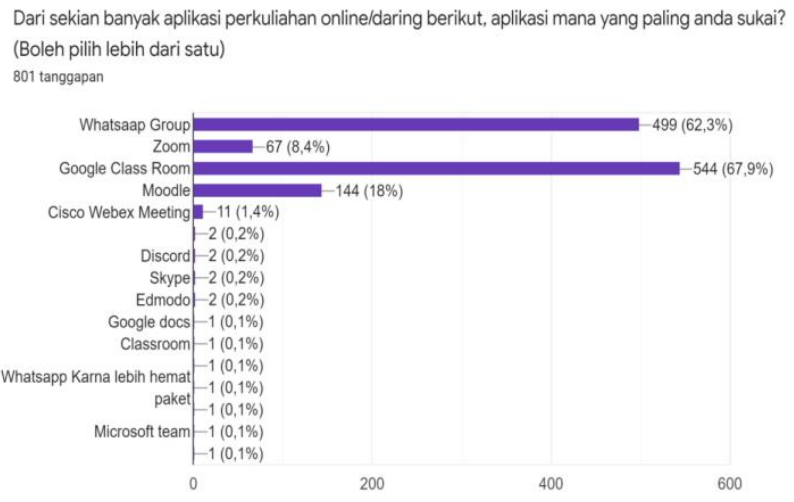

Sesuai dengan diagram 4.6 di atas dapat memberikan gambaran bahwa Persepsi Mahasiswa 
Universitas Pahlawan Tuanku Tambusai terhadap perkuliahan daring berdasarkan aplikasi yang disukai oleh mahasiswa pada saat perkuliahan daring sebagian besar menyukai aplikasi google class room yaitu dengan persentase $67,9 \%$.

\section{Diagram 4.7 \\ Distribusi Frekuensi Persepsi Mahasiswa Universitas Pahlawan Tuanku Tambusai terhadap Perkuliahan Daring berdasarkan bentuk perkuliahan daring yang dilakukan dosen}

Dari opsi berikut, bentuk perkuliahan daring/online seperti apa yang anda dan dosen anda lakuk ? (Boleh pilih lebih dari satu)

802 tanggapen

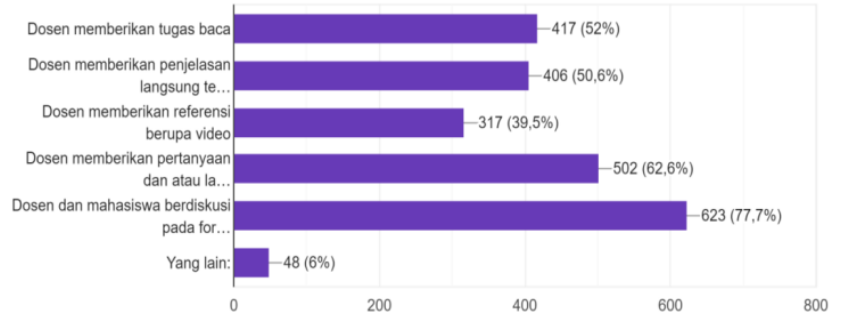

Jika dilihat dari diagram 4.7 di atas dapat mendiskripsikan bahwa Persepsi Mahasiswa Universitas Pahlawan Tuanku Tambusai terhadap perkuliahan daring berdasarkan bentuk perkuliah daring yang dilakukan antara mahasiswa dengan dosen adalah sebagian besar dosen dan mahasiswa berdiskusi pada forum dan chat group dengan persentase $77,7 \%$.

Diagram 4.8

Distribusi Frekuensi Persepsi Mahasiswa Universitas Pahlawan Tuanku Tambusai terhadap Perkuliahan Daring lebih menyenangkan dari luring

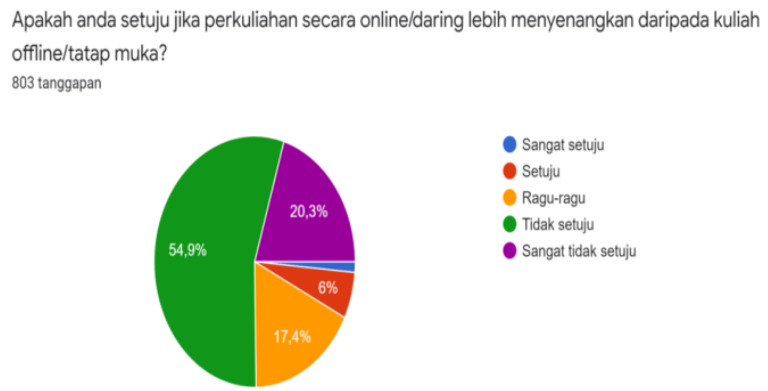

Apabila diperhatikan diagram 4.8 di atas dapat menggambarkan bahwa Persepsi Mahasiswa Universitas Pahlawan Tuanku Tambusai terhadap perkuliahan daring lebih menyenamgkan daripada perkuliahan tatap muka didapatkan hasil sebagian besar mahasiswa menjawab tidak setuju dengan persentase $54,9 \%$.

\section{Diagram 4.9 \\ Distribusi Frekuensi Persepsi Mahasiswa \\ Universitas Pahlawan Tuanku Tambusai terhadap Perkuliahan Daring berdasarkan kendala yang dihadapi selama mengikuti perkuliahan daring}

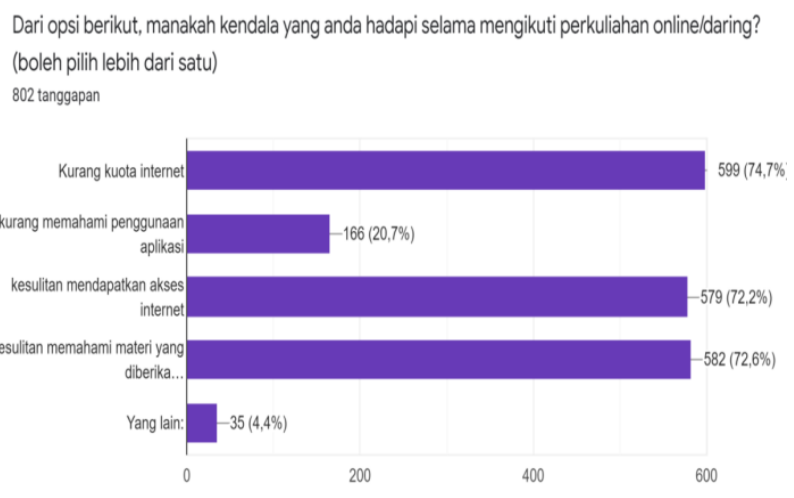

Berdasarkan diagram 4.9 di atas dapat memberikan gambaran bahwa Persepsi Mahasiswa Universitas Pahlawan Tuanku Tambusai terhadap perkuliahan daring berdasarkan kendala yang dihadapi mahasiswa selama mengikuti perkuliahan daring adalah sebagian besar dikarenakan kurang kuota internet dengan persentase $74,7 \%$.

\section{Diagram 4.10}

Distribusi Frekuensi Persepsi Mahasiswa

Universitas Pahlawan Tuanku Tambusai terhadap Perkuliahan Daring dilaksanakan lagi dimasa depan

Berdasarkan kendala yang anda hadapi, setujuhkah anda jika perkulihan online/daring ini dilaksanakan lagi di masa depan? 803 tanggapa
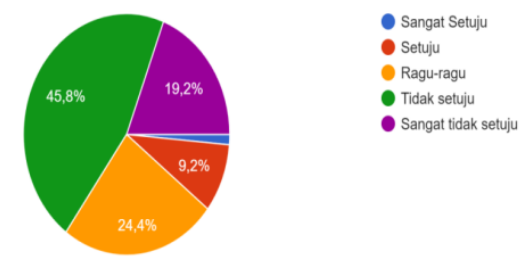

Sesuai dengan diagram 4.10 memberikan gambaran bahwa Persepsi Mahasiswa Universitas Pahlawan Tuanku Tambusai terhadap perkuliahan daring setuju dilaksanakan lagi dimasa depan, sebagian besar mahasiswa meberikan jawaban tidak setuju dengan persentase $45,8 \%$.

\section{Diagram 4.11}




\section{Distribusi Frekuensi Persepsi Mahasiswa Universitas Pahlawan Tuanku Tambusai terhadap Perkuliahan Daring berdasarkan pemahaman materi}

Apakah pada saat perkulihan online/daring berlangsung, anda dapat memahami materi perkulihan yang disampaikan oleh dosen dengan baik?

802 tangagapan
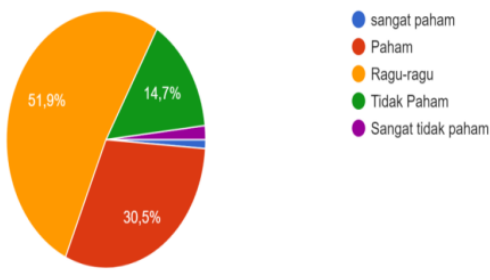

Jika diperhatikan diagram 4.11 di atas mendiskripsikan bahwa Persepsi Mahasiswa Universitas Pahlawan Tuanku Tambusai terhadap perkuliahan daring berdasarkan pemahaman materi selama mengikuti perkuliahan daring, sebagian besar mahasiswa memberikan jawaban ragu-ragu, yaitu $51,9 \%$.

\section{PEMBAHASAN}

Model pembelajaran daring menjadikan mahasiswa lebih aktif dan mencari tahu mengenai banyak hal, salah satu contohnya ialah dari penggunaan aplikasi ini. Dengan adanya kegiatan pembelajaran daring, mahasiswa belajar menggunakan suatu media pembelajaran baru, aktif berlatih, dan mengkonstruksi lingkungan pembelajarannya (Simonson, Smaldino, Albright, \& Zvacek, 2012).

Pembelajaran daring yang dilakukan Universitas Pahlawan Tuanku Tambusai selama masa pandemi Covid-19 sangat dimudahkan dengan adanya berbagai pilihan media pembelajaran. Pemilihan media pembelajaran yang akan digunakan pada umumnya berdasarkan kesepakatan bersama antara dosen dan mahasiswa. Dari berbagai pilihan tersebut, pola komunikasi yang terbentuk dapat di kelompokkan menjadi tiga macam, yaitu komunikasi satu arah, komunikasi semi dua arah, dan komunikasi dua arah.

Model komunikasi dua arah yang digunakan pada perkuliahan daring Universitas Pahlawan Tuanku Tambusai memanfaatkan media google class room. Model komunikasi ini diminati oleh banyak mahasiswa karena mahasiswa lebih mudah mengerti dan paham menggunakan google class room dalam kegiatan pembelajaran daring, hal ini senada dengan besarnya persentase penggunaan google class room sebagai media pembelajaran daring.
Selanjutnya mahasiswa juga menggunakan sistem komunikasi dua arah seperti video conference. Di Universitas Pahlawan Tuanku Tambusai sendiri, sistem komunikasi dua arah ini pada umumnya memanfaatkan media Zoom, baik yang diunduh pada smartphone, personal computer, maupun yang diakses melalui website Zoom tersebut. Penelitian menyatakan bahwa komunikasi dua arah pada kegiatan pembelajaran daring diyakini lebih efektif daripada model pembelajaran tatap muka atau konvensional (Roblyer \& Doering, 2013). Selain jenis komunikasi, gaya belajar juga mewakili sesuatu yang lebih disukai oleh mahasiswa dalam model pembelajaran. Ada tiga macam gaya belajar, yaitu visual, auditori, dan kinestetik. Bermacam gaya belajar ini apabila diakomodasi oleh lingkungan maka akan dapat mempengaruhi hasil belajar yang lebih baik (Eudoxie, 2011). Dalam hal ini mahasiswa lebih menyukai bahan perkuliahan yang dibagikan dalam bentuk visual seperti Softcopy file pdf atau power point, tulisan, dan foto mengenai bahan perkuliahan yang harus dipelajari dari dosen. Mahasiswa tersebut dikategorikan memiliki gaya belajar visual, yaitu lebih menyukai pembelajran dengan media tulisan, gambar, grafik, diagram dan hal sejenisnya (Psycharis, Botsari, \& Chatzarakis, 2014). Selain bahan berbentuk visual, mahasiswa juga diketahui menyukai media rekaman audio, video dan video conference yang menjelaskan isi dari bahan perkuliahan tersebut untuk memudahkan mereka mempelajarinya. Gaya belajar ini dikenal dengan istilah auditori, orang- orang dengan gaya belajar auditori akan lebih mudah memahami suatu hal dari suara (Rhouma,2016).

\section{SIMPULAN}

Hasil pengolahan data menunjukkan bahwa dari 806 orang mahasiswa Universitas Pahlawan Tuanku Tambusai yang tergolong kelompok millenials berdasarkan usianya, lebih nyaman untuk menggunakan aplikasi google classroom dan whatsapp untuk digunakan dalam model pembelajaran daring ini. Aplikasi tersebut telah mereka kenal sebelumnya atau mudah dipahami karena cenderung serupa dengan beberapa aplikasi yang biasa mereka gunakan di kegiatan sehari hari.. Hanya setengah dari jumlah populasi yang sebelumnya sudah mengetahui aplikasi tersebut.

Namun dengan adanya kegiatan pembelajaran daring ini mahasiswa jadi bisa belajar mengenai hal baru yang mungkin sebelumnya tidak pernah direncanakan oleh mereka. Selain itu, kebanyakan mahasiswa 
memiliki gaya belajar visual yang lebih mengarah pada media gambar, tulisan, atau foto. Hal ini berkaitan dengan kebiasaan mahasiswa dalam kegiatan sehari-hari dan rutinitas pembelajaran konvensional di kelas, yang mana bahan materi perkuliahan dibagikan kepada mahasiswa melalui power point, presentasi menggunakan grafik, diagram, atau dengan membaca dari buku-buku panduan yang disarankan oleh dosen.

Dengan mengetahui preferensi mahasiswa, para dosen atau tenaga pengajar dapat memanfaatkan media dan cara yang tepat untuk meningkatkan ketertarikan mahasiswa dalam mengikuti perkuliahan daring yang tentunya diharapkan dapat secara tidak langsung juga meningkatkan nilai akhir dan pencapaian dari mahasiswa tersebut.

\section{SARAN}

Adapun saran-saran yang dapat diberikan pada penelitian ini adalah :

1. Hasil penelitian ini diharapkan akan memberikan gambaran pada pembelajaran daring selanjutnya untuk dapat memanfaatkan media , gaya belajar, dan jenis komunikasi tertentu yang memang lebih digemari mahasiswa agar dapat menghasilkan output yang lebih baik dari kegiatan belajar mengajar secara daring di Universitas Pahlawan Tuanku Tambusai,

2. Selain itu, diperlukan adanya penelitian lebih lanjut terhadap penelitian pembelajaran daring dengan berbasis masalah, kolaboratif, dan model lainnya.

\section{DAFTAR PUSTAKA}

Davis, H., \& Fill, K. (2007). Embedding blended learning in a university's teaching culture:

Experiences and reflections. British Journal of Educational Technology, 38 (5).

Eudoxie, G. D. (2011). Learning Styles among Students in an Advanced Soil Management Class: Impact on Students ' Performance. 137-144.

Fajrian, H. (2020, maret 15). https://katadata.co.id/. Retrieved April 8, 2020, from https://katadata.co.id/berita/2020/03/15/ant isipasi-corona-nadiem-makarim-dukungkebijakan- meliburkan-sekolah

Hameed, S., Badii, A., \& Cullen, A. (2008). Effective E-Learning Integration with
Traditional Learning in a Blended Learning Environment. European and Mediterranean Conference on Information Systems .

Lashley, Y. G. (2014). Integrating computer technology in the teaching of Biology. International Journal of Biology Education , 3(2).

Mustaji, Karwanto, Dewi, U., \& Khotimah, N. (2014). Pemberdayaan Mahasiswa Untuk Berpikir Kritis, Kreatif, Dan Kolaboratif Melalui Pengembangan Perangkat Pembelajaran Kolaborasi. . Fakultas Ilmu Pendidikan, Universitas Negeri Surabaya .

Nugroho. (2012). Profesionalisme Guru SD Negeri Se-Kecamatan Warungasem KAbupaten Batang. Suatu tinjauan aspek persepsi guru tentang kepemimpinan kepala sekolah dan motivasi berprestasi guru. Varidika , 135-146.

Oh, E., \& Park, S. (2009). How are universities involved in blended instruction? Educational Technology \& Society , 12 (3).

Picciano, A. G. (2006). Blended Learning Implication for growth and access. Journal of asynchronous learning networks , 10 (3).

Psycharis, S., Botsari, E., \& Chatzarakis, G. (2014). Examining the Effects of Learning Styles, Epistemic Beliefs and the Computational Experiment Methodology On Learners' Performance Using the Easy Java. Journal Education Computer Res, vol 51, No 1, pp 91-118.

Rhouma, W. (2016). Perceptual Learning Styles Preferences and Academic. vol. 09, no. 02, pp.479-492

Roblyer, A. H., \& Doering. (2013). Integrating Educational Technology in Teaching. Boston: Pearson.

Rovai, A., \& Jordan, H. (2004). Blended Learning and Sense of Community: A comparative analysis with traditional and fully online graduate courses. International Review of Research in Open and Distance Learning , $5(2)$.

S.Alam, \& L.Jackson. (2013). A Case Study : Are Traditional Face-To-Face Lectures Still Relevant When Teaching Engineering Courses ? vol. 3, no. 4, pp. 9-16.

Saifuddin, M. F. (2016). E-Learning Dalam Persepsi Mahasiswa. Universitas Ahmad Dahlan ,102-110.

Simonson, M., Smaldino, S., Albright, M., \& Zvacek, S. (2012). Teaching and Learning at a Distance. Foundation of Distance Education . 
Singh, G., 'donoghue, J. O., \& Worton, H. (2005). A Study Into The Effects Of eLearning On

Higher Education. Journal of University Teaching \& Learning Practice, 2(1).

Tayebinik, M., \& Puteh, M. (2013). Blended Learning or E-learning? International Magazine on

Advances in Computer Science and Telecommunications (IMACST), 103-110.

Zimmerman, B. (2000). Attaining selfregulation: A social cognitive perspective. In $M$. Boekarts, P. R. Pintrich, \& M. Zeidner (Eds.), Handbook of selfregulation (pp. 13 - 39). San Diego, CA: Academic Press..

Zimmerman, B., \& Martinez-Pons, M. (1988). Construct validation of a strategy model of student selfregulated learning. Journal of Educational Psychology, Vol. 80, 284- 290 